OPEN ACCESS

Edited by:

George Grant,

University of Aberdeen,

United Kingdom

Reviewed by:

Maria Elizbeth Alvarez Sanchez,

Universidad Autónoma de la Ciudad de México, Mexico

Lilián Yépez-Mulia,

Instituto Mexicano del Seguro Social

(IMSS), Mexico

*Correspondence:

Zhenchao Zhang

zhangzhenchao525@163.com

Xiangrui Li

lixiangrui@njau.edu.cn

Specialty section:

This article was submitted to

Infectious Diseases,

a section of the journal

Frontiers in Microbiology

Received: 21 February 2020 Accepted: 03 June 2020

Published: 30 June 2020

Citation:

Zhang Z, Li Y, Wang S, Hao L, Zhu Y, Li H, Song $X$, Duan Y, Sang Y,

Wu P and LiX (2020) The Molecular

Characterization and Immunity Identification of Trichomonas vaginalis

Adhesion Protein 33 (AP33).

Front. Microbiol. 11:1433.

doi: 10.3389/fmicb.2020.01433

\section{The Molecular Characterization and Immunity Identification of Trichomonas vaginalis Adhesion Protein 33 (AP33)}

\author{
Zhenchao Zhang ${ }^{1 *}$, Yuhua Li $^{1}$, Shuai Wang ${ }^{1}$, Lixia Hao ${ }^{2}$, Yunqing Zhu ${ }^{2}$, Haoran Li ${ }^{1}$, \\ Xiaoxiao Song ${ }^{1}$, Yujuan Duan', Yuhui Sang ${ }^{1}$, Pucheng $W u^{1}$ and Xiangrui Li1,3*
}

${ }^{1}$ Xinxiang Key Laboratory of Pathogenic Biology, School of Basic Medical Sciences, Xinxiang Medical University, Xinxiang, China, ${ }^{2}$ Xinxiang Maternity and Child Health Care Hospital, Xinxiang, China, ${ }^{3} \mathrm{MOE}$ Joint International Research Laboratory of Animal Health and Food Safety, College of Veterinary Medicine, Nanjing Agricultural University, Nanjing, China

Trichomoniasis is caused by Trichomonas vaginalis (T. vaginalis), which is a widespread and serious sexually transmitted pathogen in humans. The procedure of $T$. vaginalis adherence to the host cell is the precondition for $T$. vaginalis parasitism and pathogenicity. The AP33 adhesin of T. vaginalis (TVAP33) plays a key role in the process of adhesion. In this study, the specific primers for polymerase chain reaction (PCR) were designed based on the sequence of TVAP33 (GenBank Accession No. U87098.1) to amplify the open reading frame (ORF), and the ORF was inserted into pET-32a $(+)$ to produce recombinant TVAP33 (rTvAP33). The sequence analysis indicated that the TVAP33 gene encoded a protein of 309 amino acids with $32.53 \mathrm{kDa}$, and the protein was predicted to have a high antigen index. Western blotting assay showed rTvAP33 was successfully recognized by the sera of mice experimentally infected with $T$. vaginalis, while native TVAP33 in the somatic extract of $T$. vaginalis trophozoite was as well detected by sera from rats immunized with the rTvAP33. Immunofluorescence analysis using an antibody against rTVAP33 demonstrated that the protein was expressed and located on the surface of $T$. vaginalis trophozoites. The recombinant protein was emulsified in Freund's adjuvant and used to immunize BALB/C mice three times at days 0,14 , and 28 . The result of animal challenge experiments revealed the levels of IgG, IgG1, and IgG2a, and IL-4, IL-10, and IL17 among rTvAP33 vaccinated animals were integrally increased. Moreover, the rTVAP33 vaccinated animals were apparently prolonged survival time $(26.45 \pm 4.10)$ after challenge infection with this parasite. All these results indicated that TVAP33 could be used as vaccine candidate antigen to induce cell-mediated and humoral immunity.

Keywords: $T$. vaginalis, adhesion protein 33 , molecular characterization, animal challenge, immunogenicity

\section{INTRODUCTION}

Trichomonas vaginalis is a widespread and serious sexually transmitted pathogen in humans, which causes a common infection of the urogenital system. The World Health Organization (WHO) estimated that 276 million people were infected with T. vaginalis on a global scale in 2008, increasing by $11 \%$ compared to 2005 (World Health Organization, 2012; Jarrett et al., 2019). In 
the United States, almost 5 million people are infected with T. vaginalis every year, and in Japan the infection rate in women is $24.3 \%$. Moreover, the prevalence in target populations in rural Uganda and South Africa was 23.8 and 18.0\%, respectively, (Zhang et al., 2018a). T. vaginalis can cause atypical pelvic inflammation in women, urethritis and prostatitis in men, as well as trichomonas pneumonia, bronchitis and oral lesions in newborns (Patel et al., 2018). Moreover, premature rupture of membranes, premature delivery, abortion and low birth weight may occur in pregnant women infected with $T$. vaginalis. In recent years, studies have shown that cervical cancer in women, prostate cancer in men and infertility are associated with the infection of $T$. vaginalis (Langston et al., 2019). In addition, the widespread prevalence of $T$. vaginalis increases the risk of human infection with human immunodeficiency virus (HIV) and mycoplasma (Fiori et al., 2013; Makarova et al., 2017).

At present, the prevention and treatment of trichomoniasis is based on drugs, and metronidazole is commonly used in clinical treatment (Graves et al., 2019; Vargas Rigo et al., 2019). However, an increasing number of reports confirm that there are serious problems the generation of drug-resistant strains and mutagenicity of metronidazole, and other drugs against T. vaginalis have their own shortcomings (Bitencourt et al., 2018). Therefore, considerable effort has been made to research new anti-T. vaginalis drugs. Until now, few drugs with high biological activity and low cytotoxicity have been found that can completely kill and eliminate $T$. vaginalis.

Vaccine inoculation is a good way to control infectious diseases. However, to date, there is no commercialized vaccine against trichomoniasis (Mirasol-Melendez et al., 2018; MendozaOliveros et al., 2019). Therefore, it is of great importance to identify effective and low toxicity alternative drugs and new vaccines against this parasite. The discovery of drug targets and candidate antigens is a prerequisite for exploring alternative drugs and new vaccines against $T$. vaginalis. Furthermore, much research has indicated that DNA vaccines or recombinant antigens can induce both humoral and cellmediated immune responses (Zhang et al., 2018c; Mavi et al., 2019; Zhang et al., 2019).

Trophozoites of $T$. vaginalis adhesion to host cells, an early and critical step to colonization and infection, is an intensely specific process that is mediated by the adhesion proteins including AP120, AP65, AP51, AP33, and AP23 (Ardalan et al., 2009; Nievas et al., 2018; Phukan et al., 2018). The proteins of AP65 could be secreted out of trophozoite of $T$. vaginalis and attach to the surface of trophozoites and host cells (Garcia and Alderete, 2007). However, the location of AP33 in trophozoites is not clear. These results using both antisense inhibition of gene expression and AP33 synthesis and the heterologous expression of AP33 in T. foetus confirmed a role for this protein as an adhesin in T. vaginalis (Mundodi et al., 2007). Further study showed that there were two binding regions in AP33 protein, located at the N-terminal and C-terminal of protein sequence, respectively, (Engbring and Alderete, 1998a). Indirect immunofluorescent antibody test indicated the monoclonal antibody against AP33 could significantly inhibit the adhesion of $T$. vaginalis to HeLa cell (Huang et al., 2007). Moreover, the recombinant
AP33 protein showed a high expression level and immunizeed rabbits to produce high titer antibodies, and antibody against AP33 was detected in $78 \%$ of the 50 patients infected with T. vaginalis by ELISA.

In addition, among the different genotypes of $T$. vaginalis, there is a high homology (98.2-100\%) in the AP33 gene sequence (Yuan and Gao, 2005). Results of database retrieval showed that AP33 had significant identity to the succinylCoA synthetase $\alpha$-subunit of several different organisms and virtually $100 \%$ identity to the reported $T$. vaginalis subunit (Engbring and Alderete, 1998b). All of these indicated that AP33 could be used as an excellent vaccine candidate antigen against trichomoniasis.

To date, knowledge concerning the immunogenicity of T. vaginalis proteins is still limited. In the current study, the cloning and characterization of TVAP33 was completed and the immunogenicity of recombinant TvAP33 was verified in animal experiments.

\section{MATERIALS AND METHODS}

\section{Ethics Statement}

The experiments in this study were conducted following the guidelines of the Animal Ethics Committee, Xinxiang Medical University, Henan, China (Reference No. 2015016). All efforts were made to alleviate the distress and pain of the experimental animals as much as possible. In this research, euthanasia was used at humane endpoints. Generally, euthanasia was conducted by placing the animals in a closed space and exposing them to 60$70 \% \mathrm{CO}_{2}$ for $5 \mathrm{~min}$. Occasionally, cervical dislocation was also used for confirmation of valid euthanasia.

\section{Mice and Parasites}

Six-week-old female BALB/c mice were provided by Beijing Vital River Laboratory Animal Technology Co., Ltd. (Beijing, China) and kept under SPF condition (specific pathogen free).

In this study, the strain of $T$. vaginalis was isolated from the vaginal secretions of women with some clinical symptoms of trichomoniasis at the Third Affiliated Hospital of Xinxiang Medical University. T. vaginalis were cultured on TYM medium with antibiotics (50 $\mathrm{mg} / \mathrm{ml}$ ciprofloxacin, $100 \mathrm{mg} / \mathrm{ml}$ ceftriaxone), fungicide $(2.5 \mathrm{mg} / \mathrm{ml}$ amphotericin B) and $10 \%$ calf serum in a humidified chamber containing $5 \% \mathrm{CO}_{2}$ at $37^{\circ} \mathrm{C}$. We harvested parasites at the stationary phase by centrifugation $\left(2 \times 10^{6}\right.$ parasites) and used them in subsequent research. The strain of $T$. vaginalis was identified as actin genotype E by PCRrestriction fragment length polymorphism (PCR-RFLP), which was the dominant genotype in the city of Xinxiang, Henan Province, China.

\section{Soluble Trophozoite Antigens of T. vaginalis}

A total of $5 \times 10^{7} T$. vaginalis trophozoite cells were harvested from TYM complete medium, centrifuged three times at $2500 \mathrm{rpm}$ for $10 \mathrm{~min}$ using $0.1 \mathrm{M} \mathrm{PBS}(\mathrm{pH} \mathrm{7.2)}$ to wash 
the cells. After resuspending the obtained pellet in $2 \mathrm{ml}$ PBS, the obtained solution was subjected to repeated freeze-thaw cycles three times at temperatures below $-20^{\circ} \mathrm{C}$ and $4^{\circ} \mathrm{C}$ to break the cell membrane and purify the protein. Afterward, the lysed cell mixture was treated ultrasonically on ice at a speed of $60 \mathrm{~W} / \mathrm{s}$ and then separated by centrifugation at $12000 \mathrm{rpm}$ and $4^{\circ} \mathrm{C}$ for $30 \mathrm{~min}$, after which the supernatant containing protein was obtained. The concentration of the protein samples was determined by the Bradford method, and bovine serum albumin (BSA) was used as the standard. The proteins were filtered sterilized, and finally, the obtained samples of $T$. vaginalis were aliquoted and stored at $-70^{\circ} \mathrm{C}$ for subsequent use.

\section{Total RNA Extraction of $T$. vaginalis}

The extraction of total RNA from $T$. vaginalis trophozoites was conducted by using the E.Z.N.A. ${ }^{\text {TM }}$ Total RNA Kit I (OMEGA, Zhengzhou, China) in strict accordance with the manufacturer's instructions. Water treated with diethyl pyrocarbonate (DEPC) and supplemented with ribonuclease inhibitor (TaKaRa, Dalian, China) was used to resuspend the RNA samples and RNase-free DNase I (TaKaRa) was used to treat the samples before conducting reverse transcription to avoid contamination from genomic DNA. The OD260 was measured to quantify the RNA samples, and the ratio of OD260/OD280 was used to determine its quality. RNA with OD260/OD280 values ranging from 1.9 to 2.0 was considered acceptable.

\section{Amplification of the ORF of TvAP33}

cDNA was amplified by performing RT-PCR. Primers containing protective bases (italics) and restriction enzymes (underlined) (BamH I anchored forward primer, 5/CGCGGATCCATGCTCTCCTCTTCCTTCGAGC-3/; Xho I anchored reverse primer, 5/- CCGCTCGAGTTAGATCTTGC CCATTCTCTTCATC -3/) were used in PCR to amplify the entire ORF of TvAP33 (GenBank accession no. U87098.1) from trophozoite cDNA. The ORF of TvAP33 amplified by PCR was cloned into the pMD19-T vector (TaKaRa) and transformed into E. coli (DH5a) competent cells (Yi Fei Xue Biotechnology, Nanjing, China). The recombinant pMD19-T-TvAP33 clone was amplified by PCR and digested for identification, and 3 positive clones were sequenced for further confirmation. The online tool BLAST $^{1}$ was used to analyze the sequence identity of the fragment inserted in the recombined plasmid using the GenBank database.

\section{Sequence Analysis}

The similarity between sequences was evaluated by BLASTX and BLASTP $^{2}$. CLUSTALW1.8 was used to align the sequences of adhesion proteins. The following online tools were applied for the prediction of motifs, secondary structures and signal peptides:

${ }^{1}$ http://www.ncbi.nlm.nih.gov/BLAST/

${ }^{2}$ https://blast.ncbi.nlm.nih.gov/Blast.cgi
Motifscan $^{3}$, PSIpred ${ }^{4}$, GPI Modification Site Prediction ${ }^{5}$, $\mathrm{TMHMM}^{6}$ and SignalP ${ }^{7}$.

\section{Expressing and Purifying the Proteins TvAP33 and pET-32a}

According to the method described in the reported literature (Engbring and Alderete, 1998b; Zhang et al., 2020), the protein of TvAP33 was expressed and purified. The Bradford procedure (Bradford, 1976) was applied to determine the TvAP33 protein concentration with the standard of bovine serum albumin (BSA) used as a standard. The obtained protein was stored at $-20^{\circ} \mathrm{C}$ for further usage.

Similarly, E. coli BL21 cells after transformation with the pET$32 \mathrm{a}(+)$ plasmid were induced to obtain the $\mathrm{pET}-32 \mathrm{a}$ protein with 6 histidines and TrxTag ${ }^{\mathrm{TM}}$ thioredoxin protein containing 109 amino acid residues.

\section{Antisera Against Recombined TvAP33 and $T$. vaginalis}

SD rats purchased from Beijing Vital River Laboratory Animal Technology Co., Ltd. (Beijing, China) were injected subcutaneously into multiple sites with a mixture of Freund's complete adjuvant and $0.3 \mathrm{mg}$ pure recombined TvAP33 protein (ratio 1:1) to generate a polyclonal antibody. Fourteen days later, the rats were administered one booster injection containing the mixture of Freund's incomplete adjuvant and the same antigen (ratio 1:1) and were reboosted three times at an interval of 7 days. After the entire immune procedure was completed, sera were obtained and stored for further use. Negative control serum was obtained before injection (Yanming et al., 2007).

Mice experimentally injected with $T$. vaginalis were used to collect antiserum against $T$. vaginalis (mouse antisera) 10 days post-infection.

\section{Immunoblot Analyses of Natural and Recombinant TvAP33}

SDS-PAGE was used to separate the samples that contained recombinant TvAP33 and soluble trophozoite antigens of T. vaginalis, and a nitrocellulose membrane (Millipore, Shanghai, China) was used for protein hybridization after separating the proteins in the gel. The membranes were blocked with TBST containing Tween 20, Tris-buffer saline and 5\% (w/v) skim milk powder and then incubated with mouse antiserum $(1: 100)$ or rat antiserum (1:200) as the primary antibodies for $1 \mathrm{~h}$ at $37^{\circ} \mathrm{C}$. Then, TBST was used to wash the membranes three times, and horseradish peroxidase (HRP)-conjugated goat anti-mouse IgG and HRP-conjugated goat anti-rat IgG (Sigma, Shanghai, China) were added to the membranes for $1 \mathrm{~h}$ at $37^{\circ} \mathrm{C}$. Finally, a 3 , 3/-diaminobenzidine tetrahydrochloride (DAB) kit (Boster BioTechnology, Wuhan, China) was used to detect the bands strictly following the manufacturer's instructions.

\footnotetext{
${ }^{3}$ https://myhits.sib.swiss/cgi-bin/motif_scan

${ }^{4}$ http://bioinf.cs.ucl.ac.uk/psipred/

${ }^{5} \mathrm{http} / / /$ mendel.imp.ac.at/sat/gpi/gpi_server.html

${ }^{6}$ http://www.cbs.dtu.dk/services/TMHMM/

${ }^{7}$ http://www.cbs.dtu.dk/services/SignalP/
} 


\section{Expression and Location of TvAP33 in Trophozoites of $T$. vaginalis by Immunofluorescence}

Harvested T. vaginalis trophozoite cells were washed three times with PBS ( $\mathrm{pH}$ 7.2), and smeared on a poly-L-lysine treated glass slide for $15 \mathrm{~min}$. Then, the trophozoites were fixed using PBS containing 4\% paraformaldehyde for $10 \mathrm{~min}$ at room temperature, permeabilized using PBS containing 1\% TritonX100 for $10 \mathrm{~min}$, washed three times with PBS and blocked using PBST containing $4 \%(\mathrm{w} / \mathrm{v}) \mathrm{BSA}$ for $1 \mathrm{~h}$ at $37^{\circ} \mathrm{C}$. After the slides were washed three times with PBS, rat antiserum against TvAP33 (dilution ratio $1: 100$ ) and control rat serum were added to the slides overnight at $4^{\circ} \mathrm{C}$. The slides were washed three times with PBS, treated with goat anti-rat IgG antibody (Beyotime, Shanghai, China) labeled with Cy3 (dilution ratio 1:1,000) and incubated in the dark for $40 \mathrm{~min}$. After three washes in PBS, DAPI (Beyotime) was used to stain the nuclei for $15 \mathrm{~min}$ in darkness. After washing with PBS, fluorescent mounting medium (Beyotime) was added, and the cells were examined by laser confocal microscopy (Nikon, Beijing, China).

\section{Immunization and Challenge Infection}

In total, $80 \mathrm{BALB} / \mathrm{c}$ mice aged 6 weeks old were classified at random into four groups (20/group) and injected subcutaneously with $100 \mu \mathrm{g}$ of recombinant TvAP33 protein and Freund adjuvant (1:1), pET-32a protein mixed with Freund adjuvant (1:1), or the same volume of Freund adjuvant alone. The remaining group of mice was used as the blank control and received no inoculation. The animals in all groups were vaccinated three times at 0 day (Freund's complete adjuvant was used), 14 day (Freund's incomplete adjuvant was used) and 28 day (Freund's incomplete adjuvant was used) separately. Ten days after the last vaccination, each mouse in the experiment was challenged with $1 \times 10^{7}$ trophozoites of $T$. vaginalis intraperitoneally, and the survival of mice was monitored throughout the month after challenge. Animals showing symptoms were subjected to euthanasia by $\mathrm{CO}_{2}$.

Thirty days later, the following formula was used to calculate the survival rate of mice challenged with $T$. vaginalis: the number of surviving mice/the number of mice before immunization $\times 100 \%$.

\section{The Use of Enzyme-Linked Immunosorbent Assay (ELISA) to Determine Antibody Levels in Sera}

The collection of mouse blood samples in each group $(n=5)$ was conducted at $0,14,28$, and 42 days, and the obtained serum samples were stored at $-20^{\circ} \mathrm{C}$ in order to further evaluate antibodies and measure cytokines. Indirect ELISA was performed to detect IgG isotypes and specific anti-TvAP33 antibodies as described in a previous study with a few modifications (Zhang et al., 2018c). In brief, microtiter plates (Costar, New York, NY, United States) were coated with recombinant TvAP33 in carbonate buffer $(2.5 \mu \mathrm{g} / \mathrm{ml}, 100 \mu \mathrm{l} /$ well $)$ with a $\mathrm{PH}$ value of 9.6 overnight at $4^{\circ} \mathrm{C}$ and blocked with $4 \%$ BSA for $2 \mathrm{~h}$ at $37^{\circ} \mathrm{C}$. A mouse serum dilution (ratio $=1 / 10$, PBS was used as the diluent) was added to the wells, and the plates were incubated at $37^{\circ} \mathrm{C}$ for $2 \mathrm{~h}$. After the plates were washed three times with PBST, the plates were treated with the HRPconjugated secondary antibodies goat anti-mouse IgG2a, IgG1, and IgG (SouthernBiotech, Birmingham, AL, United States). Finally, $100 \mu \mathrm{l}$ of 3,3,5,5-tetramethylbenzidine was added into each well, and then $100 \mu \mathrm{l}(2 \mathrm{M})$ sulfuric acid was added to terminate the reaction. The light absorption at $450 \mathrm{~nm}$ was measured by an automatic ELISA reader (MULTISKAN FC, Thermo Fisher Scientific, Waltham, MA, United States) and all tests were completed in triplicate.

\section{Cytokine Determination}

The cytokine expression levels were determined using serum samples from all experimental rodents. Commercial ELISA kits (Boster, Wuhan, China) were used to measure IFN- $\gamma$, interleukin-2 (IL-2), interleukin-4 (IL-4), interleukin-10 (IL10), and interleukin-17 (IL-17). Recombinant IFN- $\gamma$, IL-17, IL10 , IL-4, and IL-2 were used to generate the corresponding standard curves based on which the cytokines were quantified. The analyses were conducted based on data obtained from 3 individual experiments.

\section{Statistical Analyses}

The SPSS statistical package (SPSS for Windows 16; SPSS Inc., Chicago, IL, United States) was utilized to apply Duncan's multiple range test and one-way analysis of variance (ANOVA) to determine the statistical significance of biological research data, such as the expression of cytokines and corresponding antibody levels. The survival periods were compared using the Kaplan-Meier method. Tests of the differences among groups were conducted, and the threshold value of $p<0.05$ indicated that the difference was statistically significant.

\section{RESULTS}

\section{Cloning and Sequence Analysis of TvAP33}

A 930 bp ORF of TvAP33, which encodes a protein of 309 amino acids with a molecular mass of $32.53 \mathrm{kDa}$, was found that started from the ATG initiation codon and ended at the stop codon of TAA, as demonstrated by gel electrophoresis (Figure 1A) and sequencing. By sequence analysis, it was discovered that the ORF of TvAP33 contained 35 strongly basic amino acid residues, 24 strongly acidic amino acid residues, 113 hydrophobic amino acid residues and 62 polar amino acid residues with a theoretical pI of 9.47. In comparison to known protein and nucleotide sequences recorded by the NCBI database ${ }^{2}$, the TvAP33 nucleotide sequence was $99 \%$ identical to the T. vaginalis succinyl CoA synthetase-3 alpha-subunit (L31931.1) and hypothetical protein (XM_001328094.1) sequence. The TvAP33 amino acids sequence exhibited $99 \%$ homology to the hypothetical protein of T. vaginalis (XP_001328129.1) sequence and 97\% homology to the Succinyl-CoA synthetase subunit alpha-1 of $T$. vaginalis (P53399.1) sequence in NCBI. In the predicted protein, one 
A



B
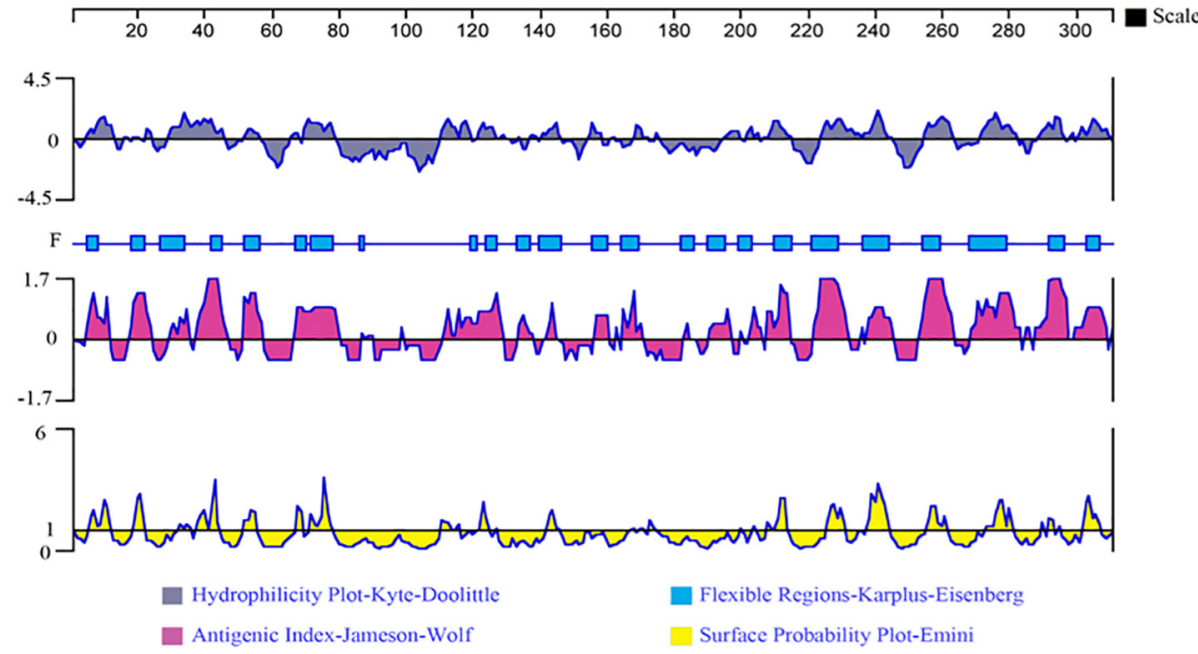

FIGURE 1 | Amplification and bioinformatics analysis of the TVAP33 gene. (A) Agarose gel electrophoresis of the TVAP33 ORF. (Lane M) DNA molecular weight marker DL 10000 (values are in bp); (Lane 1) the ORF of TVAP33. (B) The linear-B cell epitopes of TVAP33 predicted by DNASTAR in terms of hydrophilicity plot, flexible regions, antigenic index, and surface probability rules.

$\mathrm{N}$-glycosylation site and nineteen phosphorylation sites were predicted, but no transmembrane domains, GPI anchors or signal peptides were discovered. As shown in Figure 1B, the protein had seven hydrophilic regions, 4-12, 29-46, 65-78, 223-245, 254-262, 271-281 and 288-309, and nine highly antigenic indices and consecutive regions, $4-12,17-23,29-45,51-$ $56,66-79,111-128,190-213,221-244$ and $253-308$, and many regions of TvAP33 were flexible regions. The protein also contained three Succinyl-CoA synthetase regions, one CoA binding site, one CoA-ligase domain, and one $\mathrm{NAD}(\mathrm{P})$ binding domain of glutamate dehydrogenase. $\mu \mathrm{m}$

\section{Expressing and Purifying Recombinant TvAP33}

The SDS-PAGE result revealed that the supernatant of bacterial sonication extraction exhibited the highest levels of recombinant TvAP33, which was subsequently purified from the supernatant using Ni-NTA chromatography and isolated by SDS-PAGE gel as an individual band with a molecular weight of $51 \mathrm{kDa}$ (Figure 2A). The molecular mass of the recombinant protein was deduced to be $32.53 \mathrm{kDa}$ after subtracting the fused protein of $18 \mathrm{kDa}$.

\section{Analyzing the Native and Recombinant TvAP33 Using Immunoblot}

The immunoblot results revealed that the recombinant TvAP33 protein was recognized by serum from mice subjected to artificial $T$. vaginalis infection instead of serum from healthy mice (Figure 2B). The western blot results also revealed the native TvAP33 protein was recognized by rat anti-TvAP33 serum, which

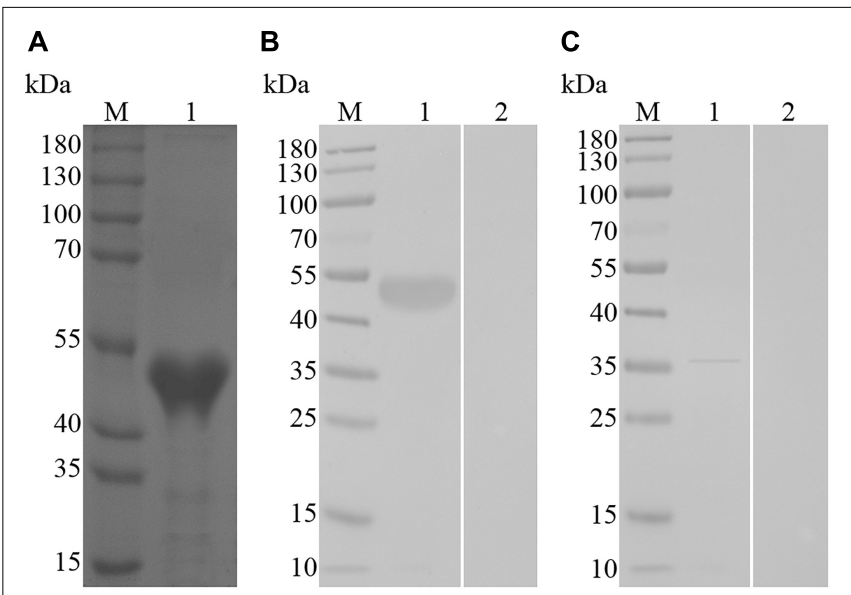

FIGURE 2 | (A) SDS-PAGE of purified recombinant TVAP33 protein. (Lane M) Protein mark (values are in kDa); (Lane 1) recombinant TVAP33 protein. (B) Immunoblot for recombinant TVAP33. (Lane M) Protein mark (values are in $\mathrm{kDa}$ ); (Lane 1) recombinant TVAP33 protein probed with serum from mice experimentally infected with T. vaginalis as the primary antibody; (Lane 2) recombinant TVAP33 protein probed with serum of normal mice as the primary antibody. (C) Immunoblot of crude somatic extracts of $T$. vaginalis trophozoites. (Lane M) Protein mark (values are in kDa); (Lane 1) crude somatic extracts of $T$. vaginalis trophozoites probed with serum from rats immunized with the TVAP33 protein; (Lane 2) crude somatic extracts of T. vaginalis trophozoites probed with serum of normal rats without immunization as the primary antibody.

was a band with a molecular mass of approximately $36 \mathrm{kDa}$ in the somatic extraction of $T$. vaginalis trophozoites (Figure 2C) and slightly larger than the predicted protein. 


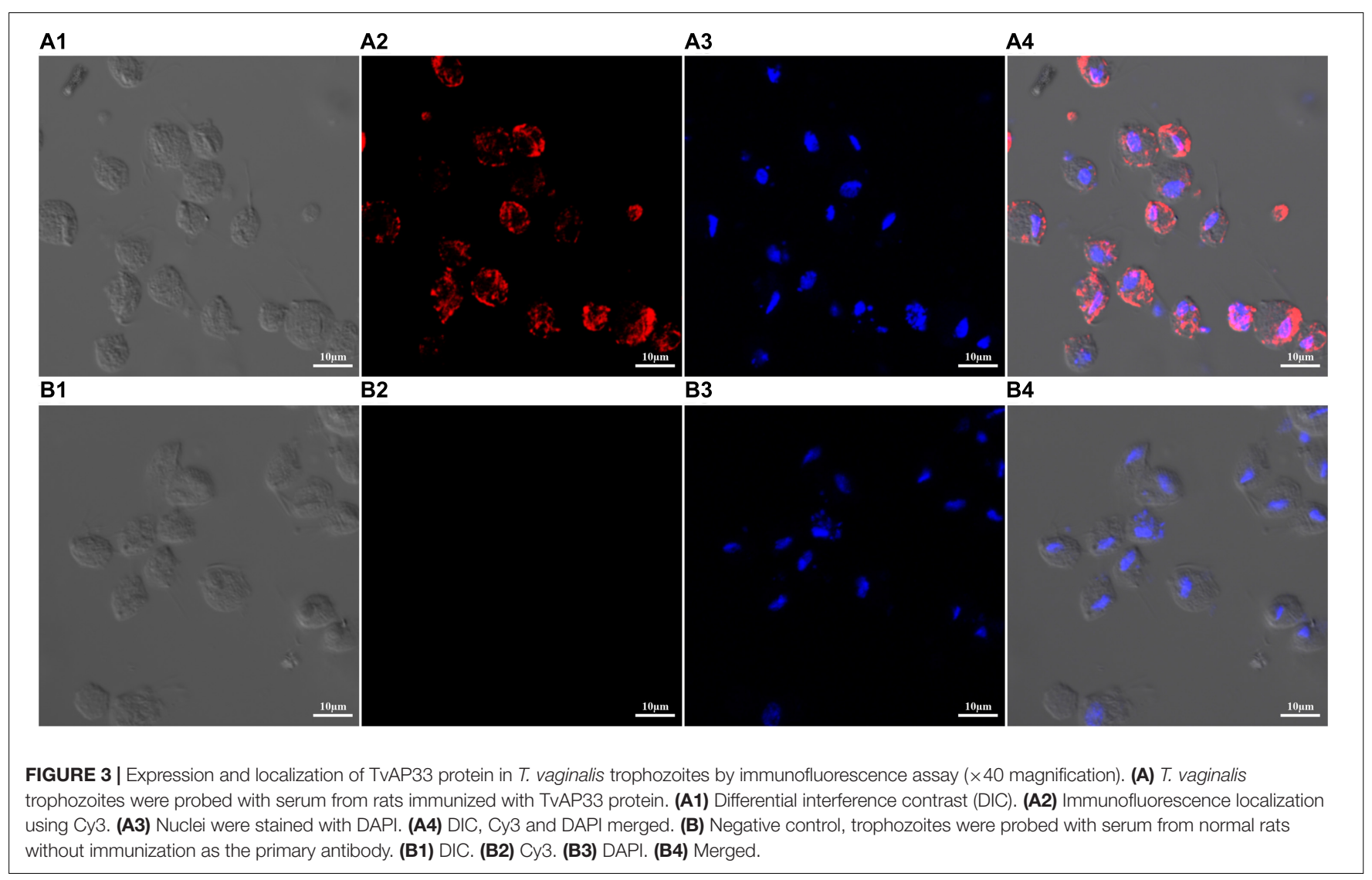

\section{Expression and Location of TvAP33 in Trophozoites of $T$. vaginalis}

The expression and location of TvAP33 protein was investigated in trophozoites (Figure 3) with anti-rTvAP33 serum. It was revealed that the trophozoites were stained by the fluorescent label, which was absent from the slides in the negative control group, and the location of TvAP33 was mainly on the surface of trophozoites.

\section{Evaluating the Protective Effect of Inoculation on Experimental Rodents Against Pathogen Challenge}

$\mathrm{BALB} / \mathrm{c}$ mice were used to investigate the protection of the recombinant protein as a vaccine antigen against artificial infection with $T$. vaginalis. The mice were subjected to one primary immunization and two booster immunizations (Table 1) and then injected intraperitoneally with $1 \times 10^{7} \mathrm{~T}$. vaginalis trophozoites. The survival rate of the different groups of mice challenged with $T$. vaginalis is presented in Figure 4. The survival rate of the mice in the TvAP33 group was significantly higher than that of the blank, Freund adjuvant and pET-32a protein groups. In the blank, Freund adjuvant and pET-32a protein groups, most mice (75-80\%) died within 18 days. Moreover, the survival time of mice subjected to TvAP33 injection $(26.45 \pm 4.10, P<0.05)$ was significantly longer
TABLE 1 | Immunization protocol in experimental and control groups.

\begin{tabular}{lccc}
\hline Groups & 1st (0 Day) & 2nd (14 Days) & 3rd (28 Days) \\
\hline Blank control & No immunity & No immunity & No immunity \\
Adjuvant control $(\mu \mathrm{l})$ & 200 & 200 & 200 \\
pET-32a protein control $(\mu \mathrm{g})$ & 100 & 100 & 100 \\
Recombinant TvAP33 protein $(\mu \mathrm{g})$ & 100 & 100 & 100 \\
\hline
\end{tabular}

than that of the mice injected with Freund adjuvant or pET32a protein.

\section{Humoral Immunoreactions}

To evaluate the different antibody responses induced by the 3 sequential vaccinations, the distribution pattern of IgG2a and IgG1 isotypes as well as the IgG level were examined each time after injection. In comparison to those in the control group, the IgG levels in serum of mice injected with TvAP33 were significantly higher $(P<0.001)$. In addition, the OD value of IgG continually increased when the animals were injected with TvAP33, and the IgG titers peaked after at 3rd immunization. No significant differences in IgG levels were discovered among the control groups (Figure 5A). In comparison to those in mice in the control groups, the levels of IgG1 and IgG2a in mice subjected to TvAP33 injection were among the highest $(P<0.001$; Figures 5B,C), and IgG2a levels were obviously 


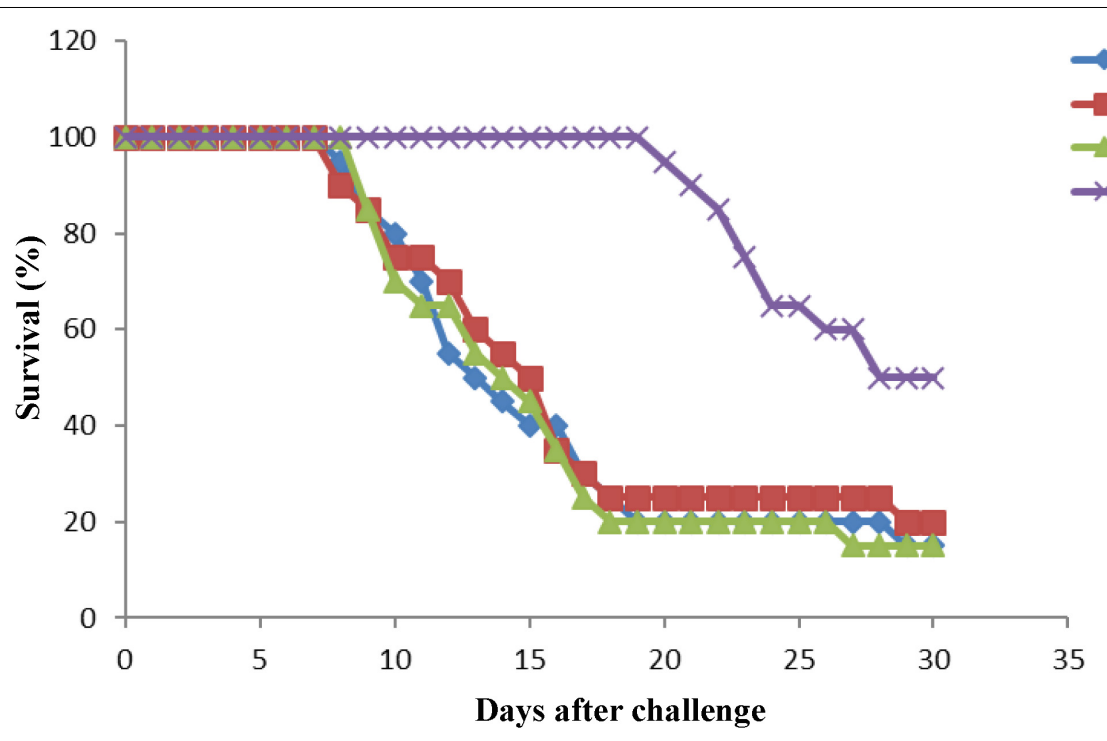

FIGURE 4 | Survival curve of mice after challenge infection with T. vaginalis trophozoite actin genotype $\mathrm{E}$ strain. Mice were challenged with $10^{7}$ trophozoites of the $T$. vaginalis actin genotype $\mathrm{E}$ strain intraperitoneally 10 days after the last vaccination.

less than IgG1, suggesting the induction of Th2-type cellular immunity by TvAP33.

\section{Cytokine Levels in Sera of Immunized Mice}

As shown in Figure 6, serum samples collected at days 0, 14,28 , and 42 were used to measure the levels of IFN- $\gamma$, IL-2, IL-4, IL-10, and IL-17 in the experimental groups. The results indicated that the quantities of IL-4, IL-10, and IL-17 (Figures 6C-E) in mice injected with TvAP33 were significantly higher than those in the control groups on days 14,28 , and 42 after vaccination $(P<0.001)$, and the levels of IL-4, IL-10, and IL-17 were highest throughout the whole experiment after the 3 rd immunization. However, the IFN- $\gamma$ and IL-2 levels of the experimental groups were not significantly different from those of the controls (Figures 6A,B).

\section{DISCUSSION}

The colonization of the urogenital tract of humans by the protozoan parasite $T$. vaginalis is responsible for trichomoniasis (Kassai et al., 1988). With the aim of preventing and controlling contagious diseases, vaccines are normally developed as the method to block pathogens with the most cost effective performance (Peggy et al., 2015; Smith and Garber, 2015). Nevertheless, the most difficult step in developing vaccines is identifying the appropriate candidate antigens. Adherence of the parasite to the vaginal epithelium, a property key to colonization and infection, is a highly specific event that is mediated by the adhesins AP120, AP65, AP51, AP33, and AP23 (Alderete and Garza, 1988; Arroyo et al., 1992). These five proteins reside on the surface of $T$. vaginalis. The association between the amounts of adhesins and the levels of cytoadherence has been demonstrated. There were two binding regions in AP33 protein, which were located at the $\mathrm{N}$-terminal and C-terminal of protein sequence, respectively, (Engbring and Alderete, 1998a). Huang et al. confirmed that the monoclonal antibody against AP33 could significantly inhibit the adhesion of $T$. vaginalis to HeLa cell (Huang et al., 2007). Thus, AP33 played an important role in adhesion to host cells and could be used as candidate vaccine antigen to control trichomoniasis. In our study, molecular properties of TvAP33 were analyzed, and the immunoprotective effect of TvAP33 against $T$. vaginalis was identified. Moreover, the gene sequence of TvAP33 was $983 \mathrm{bp}$, which contained a $930 \mathrm{bp}$ ORF. The protein encoded by the TvAP33 ORF contains 309 amino acid residues, the molecular weight of which is $32.53 \mathrm{kDa}$, which are consistent with previous studies (Engbring and Alderete, 1998b). Based on the DNASTAR analysis result of the protein sequence of TvAP33, TvAP33 was determined to have strong antigenicity due to outstanding surface probability and antigenic index resulting from the extensively distributed hydrophilic and flexible regions in the protein.

Alignment between TvAP33 and the available sequences in NCBI databases showed that the nucleotide sequence of TvAP33 had $99 \%$ to T. vaginalis succinyl CoA synthetase-3 alpha-subunit and the protein sequence of TvAP33 had 97\% to the SuccinylCoA synthetase subunit alpha-1 of $T$. vaginalis. In addition, BLASTX and BLASTP analyses revealed that three Succinyl-CoA synthetase regions, one CoA binding site, one CoA-ligase domain and one $\mathrm{NAD}(\mathrm{P})$ binding domain of glutamate dehydrogenase existed in the TvAP33 sequence. Engbring et al. indicated that the AP33 sequences were almost identical to the three reported sequences encoding the T. vaginalis $\alpha$-subunit of Succinyl-CoA synthetase, with two base changes for ap33-1, one base change for ap33-2 and three base changes for ap33-3, resulting in only one amino acid change for AP33-1 (Engbring and Alderete, 1998b). 


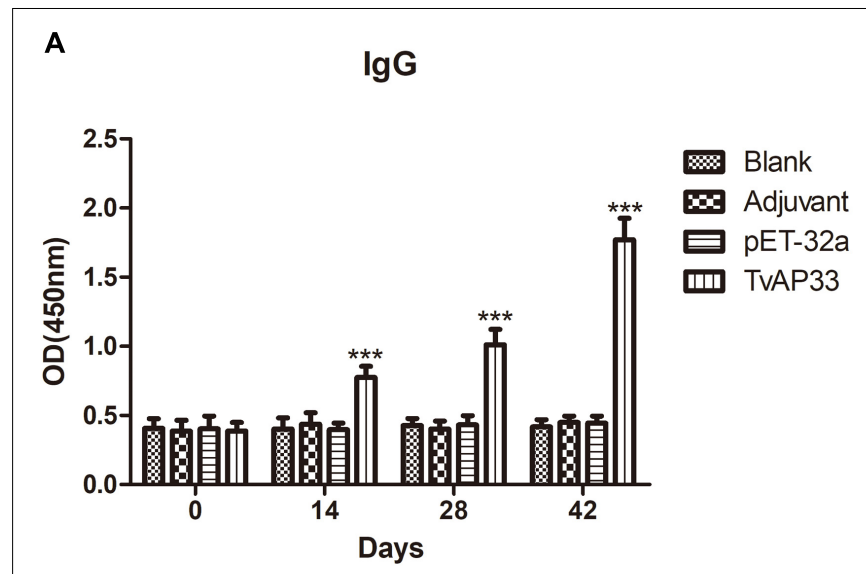

B
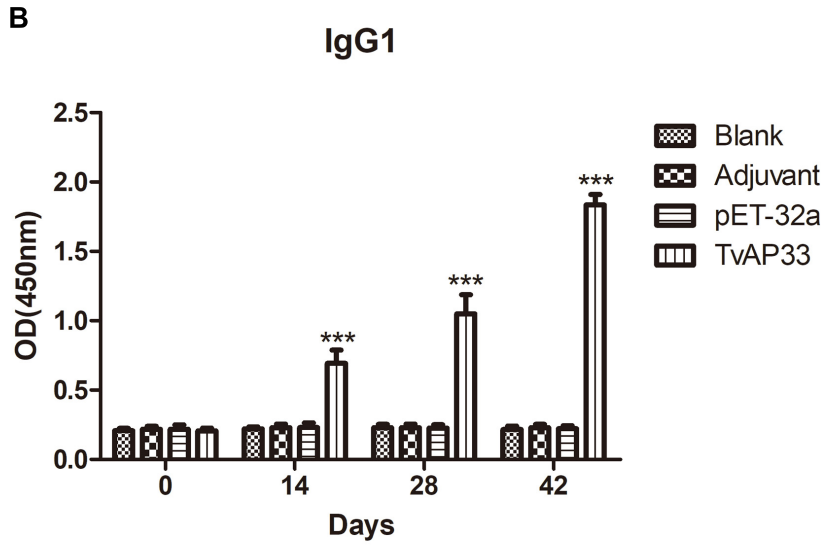

C

IgG2a

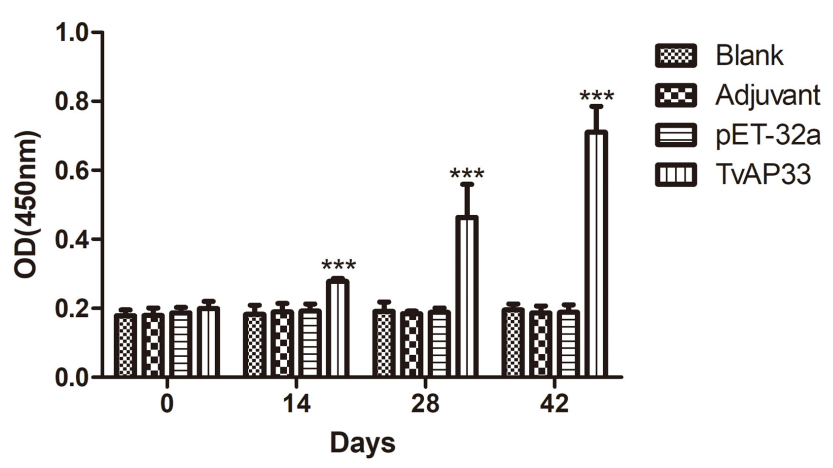

FIGURE 5 | The dynamics of humoral response in BALB/c mice induced by recombinant TVAP33 protein. The BALB/c mice were randomly divided into four groups of five mice each $(n=5)$. The BALB/c mice in group were immunized with recombinant protein TvAP33 mixed with Freund adjuvant (1:1), pET-32a protein mixed with Freund adjuvant (1:1), or Freund adjuvant alone, and the rest of the group as a blank control. The titers of IgG and the subclasses IgG1 and IgG2a were detected on days $0,14,28$, and 42 . The results were expressed as mean $\pm \mathrm{SD}$ with respect to absorbance at $450 \mathrm{~nm}$. Statistically significant differences $(P<0.05)$, $(P<0.01)$, and $(P<0.001)$ were indicated by $\left(^{\star}\right),\left(^{* *}\right)$, and $\left(^{* * *}\right)$ in different groups at the same time point, respectively. (A) lgG. (B) lgG1. (C) lgG2a.

However, whether TvAP33 has the catalytic activity of SuccinylCoA synthetase and glutamate dehydrogenase in the parasitic process of $T$. vaginalis needs further study.

Additionally, sequence analysis showed that there were almost no similarities in the amino acid epitope sequences between TvAP33 and the human homolog sequences, which would avoid potential autoimmune problems in future applications. Overall, the expression of TvAP33 as a functional protein was sustained throughout the whole life cycle of $T$. vaginalis, especially in the process of adherence to host cells (Garcia and Alderete, 2007). And the recombinant AP33 protein showed a high expression level and immunized rabbits to produce high titer antibodies, and antibody against AP33 was detected in patients infected with $T$. vaginalis by ELISA (Liang et al., 2006). Consequently, TvAP33 is qualifies as an ideal candidate for vaccine development due to the above advantages.

We found that a band with a molecular weight of $36 \mathrm{kDa}$ in the somatically extracted $T$. vaginalis trophozoites was recognized by the serum raised against recombinant TvAP33. The molecular weight of native TvAP33 was slightly larger than that of the predicted protein, which was $32.53 \mathrm{kDa}$. The TvAP33 protein might be post-translationally modified since it possesses phosphorylation and glycosylation sites according to the sequence analyses.

According to the results of western blots, serum samples from mice subjected to experimental infection of $T$. vaginalis trophozoites recognized the recombinant TvAP33, indicating that the immune system was able to recognize TvAP33 which subsequently induced an antibody response.

Protein localization studies in parasites helps to understand the function of localized proteins and adhesion proteins, based on which TvAP33 is normally considered to be involved in cellular adhesion. In the current study, it was verified that TvAP33 was located mainly at the surface of trophozoites. Previous study showed that two domains interactive with host cell surfaces were identified at distinct parts of AP33: one in the N-terminal half of the protein, and the other within 24 residues in the 


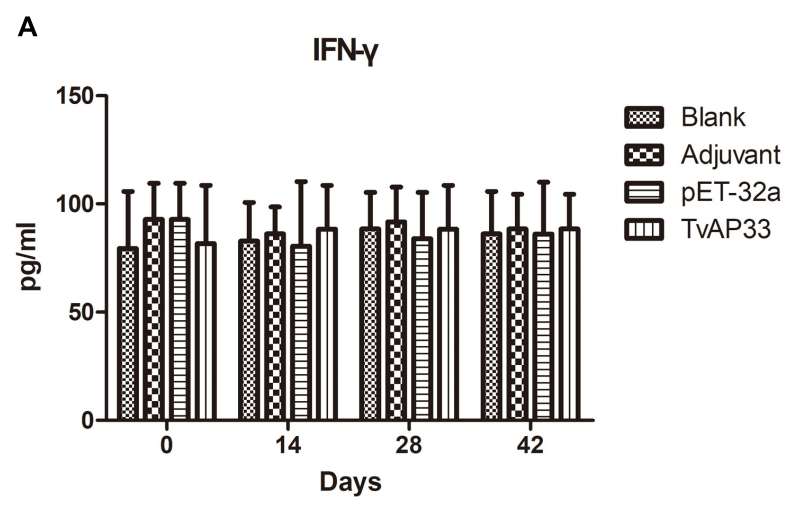

B

IL-2

C

IL-4

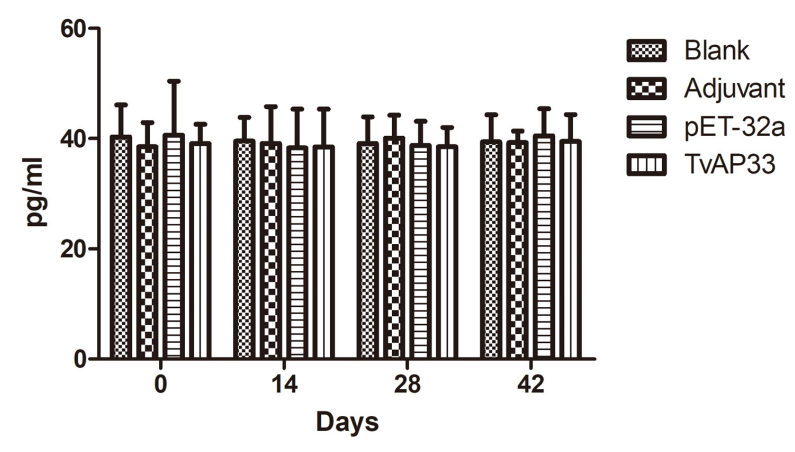

D
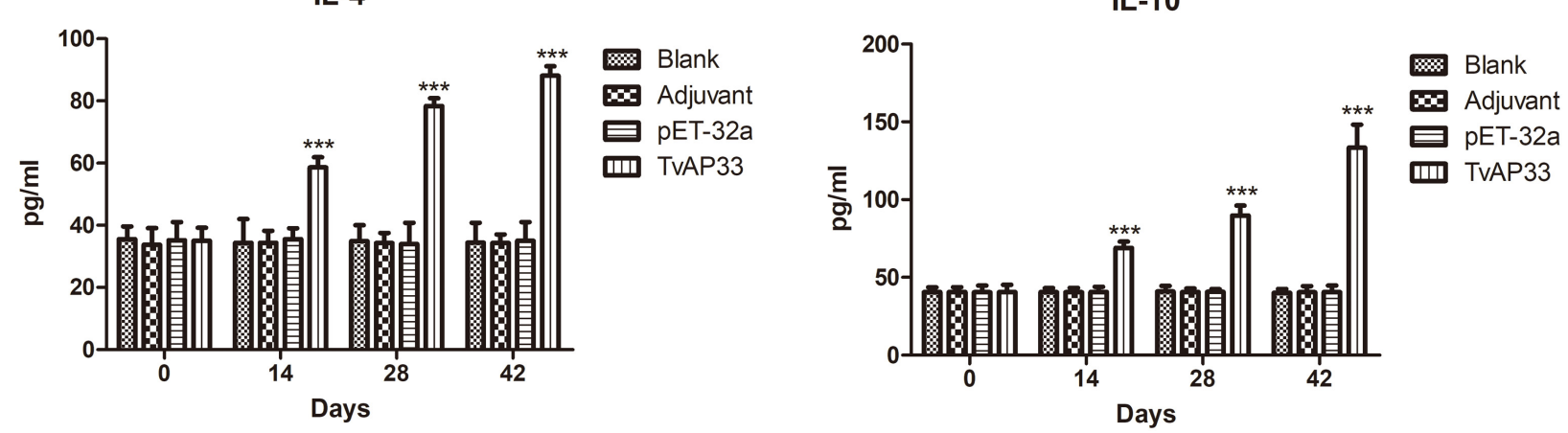

E

IL-17

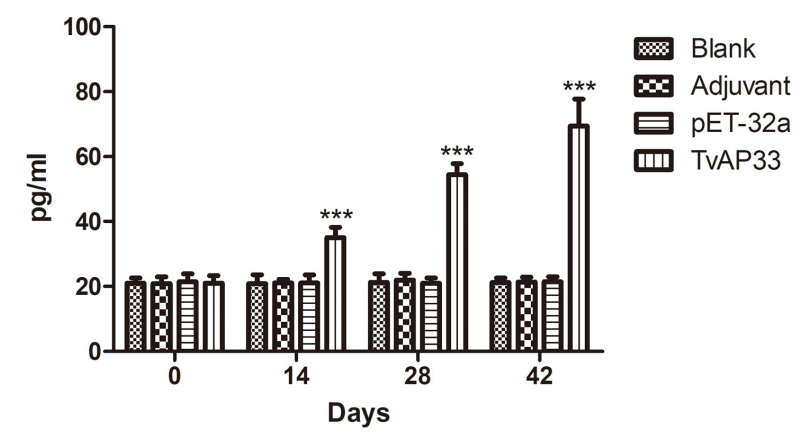

FIGURE 6 | Cytokine production. The BALB/c mice were randomly divided into four groups of five mice each ( $n=5)$. The BALB/c mice in the appropriate groups were immunized with recombinant protein TVAP33 mixed with Freund adjuvant (1:1), pET-32a protein mixed with Freund adjuvant (1:1), Freund adjuvant alone and the last group as blank controls. The levels of cytokines were determined by antigen-captured ELISA at days $0,14,28$, and 42 , and the comparison results are expressed as mean $\pm \mathrm{SD}$ of $\mathrm{pg} / \mathrm{ml}$. Statistically significant differences $(P<0.05),(P<0.01)$, and $(P<0.001)$ are indicated by $\left({ }^{\star}\right)$, $\left({ }^{\star \star}\right)$, and $\left({ }^{\star \star \star}\right)$ in different groups at the same time point. (A) IFN- $\gamma$. (B) IL-2. (C) IL-4. (D) IL-10. (E) IL-17.

C-terminal third (Engbring and Alderete, 1998a). So, the protein is involved in the attachment of the parasite to the host cell during the contact process between host cells and parasites. Whether TvAP33 adheres to the host cell surface in a ligandreceptor manner on the trophozoites of the $T$. vaginalis surface needs additional studies. However, sequence analysis showed that no transmembrane domains or signal peptides were discovered in TvAP33. How TvAP33 is localized on the parasite surface needs further study.
Cytokines play an essential role in activating Th cells (Paintlia et al., 2002). Known as an inflammatory factor, IFN- $\gamma$, defends against infections by pathogens and activates Th1 cells (Xu et al., 2016). IL-2 promotes the differentiation of $\mathrm{T}$ cells into effector $\mathrm{T}$ cells and into memory $\mathrm{T}$ cells when the initial $\mathrm{T}$ cell is also stimulated by an antigen, thus helping to fight off infections (Liao et al., 2011). In addition, IFN- $\gamma$ is often considered as a marker of Th1 cells, which express a large amount of IL-2. In this research, it was indicated that TvAP33 could not induce the expression of 
IFN- $\gamma$ and IL-2, which indicated that as a vaccine, TvAP33 could not induce a Th1 immune response.

IL-4 promotes the proliferation, differentiation and maturation of $\mathrm{B}$ cells and the differentiation of $\mathrm{CD} 4^{+} \mathrm{T}$ cells to Th2 cells, along with antibody expression, and it is considered a cytokine marker of Th2 cells (Isabelle et al., 2013). IL-10 is an important cytokine that plays an essential role in inflammation and the regulation of immunity. Moreover, the expression of Th1 cytokines, MHC class II antigen and costimulatory molecules is downregulated by IL-10 in macrophages (Beebe et al., 2015). The antibody response, proliferation and survival of $\mathrm{B}$ cells are enhanced, and the activity of NF- $\mathrm{B}$ is blocked by IL-10 (Wei et al., 2015). In addition, IL-10 participates in regulating the JAK-STAT signaling pathway (Su et al., 2017). Xie et al. reported that the vaccine containing the recombined $\alpha$-actinin subunit of $T$. vaginalis as the antigen stimulated a significant increase in IL-10 levels (Xie et al., 2017). In this study, the recombinant protein TvAP33 resulted in significantly increased IL-4 and IL-10 expression in mice vaccinated with TvAP33. This proved TvAP33 as vaccine could induce Th2 immune response.

Numerous immune regulatory functions have been reported for the IL-17 family of cytokines, presumably due to their induction of many immune signaling molecules ( $\mathrm{Li}$ et al., 2015; Ma et al., 2019). The most notable role of IL-17 is its involvement in inducing and mediating proinflammatory responses (van Dalen et al., 2019). IL-17 is commonly associated with allergic responses. IL-17 is expressed by Th17 cells, which are a subset of $\mathrm{CD}^{+}$cells (Wright et al., 2007). In the current study, TvAP33 was capable of stimulating high IL17 levels.

The production of antibodies specific to pathogens not only plays an important role in regulating the immune reaction mediated by cells but also suppresses parasites adhering to host cells through receptor molecules (Zhang et al., 2018b). In addition, intracellular parasites are also coated and killed by macrophages, which are recruited by these antibodies (Zhang et al., 2019). In the current study, in comparison to the levels in mice receiving the control vaccine, the anti$T$. vaginalis IgG levels in mice vaccinated with recombinant TvAP33 were increased. Further analyses of IgG subclasses revealed that the levels of IgG1 were higher than those of IgG2a, suggesting that TvAP33 was capable of inducing a Th2mediated immune response and thus exerted an important effect on the immunity of hosts against T. vaginalis. Thus, TvAP33 could stimulate significant expression of IL-4 and IL-10 (Th2type cytokine).

At present, efforts have been made to develop vaccines against T. vaginalis (Abraham et al., 1996; Smith and Garber, 2015). Among these studies, 2 were focused on producing a vaccine that contained whole $T$. vaginalis cells and was injected subcutaneously into mice that were challenged through the vagina. It has also been reported that intraperitoneal injection of $T$. vaginalis can be used as a mouse model to study vaccines against $T$. vaginalis (Xie et al., 2017). Previous studies indicated that the initial infection efficiency of intraperitoneal injection was higher than that of vaginal infection (Hernández et al., 2010; Xie et al., 2017). In our current study, the effect of TvAP33 against $T$. vaginalis was evaluated by intraperitoneal challenge with $1 \times 10^{7}$ trophozoites.

In vivo protection is considered one of the most critical outcomes in assessing the value of a candidate vaccine (Hammond et al., 1990; Peggy et al., 2015). The survival time and rate of the animals that receive vaccination and are challenged with parasites are considered among the most widely accepted ways of evaluating the protection effect of a vaccine. In our study, TvAP33 had a protective effect $(50 \%)$ that was higher than that of the controls. Moreover, survival assay results revealed a remarkable increase in survival time $(26.45 \pm 4.10$ days $)$ due to TvAP33 vaccination, suggesting that the vaccine was able to induce specific immune responses against $T$. vaginalis infections in $\mathrm{BALB} / \mathrm{c}$ mice. Nevertheless, whether the immune responses induced by TvAP33 could protect the challenged mice from trichomoniasis and subsequent mortality in a longer follow-up period needs further study.

In conclusion, the cloning of the TvAP33 gene and the expression of the TvAP33 protein were completed. Immunoblots showed that TvAP33 was immunogenic and could stimulate the production of specific antibodies. Immunofluorescence indicated that TvAP33 was located on the surface of the trophozoites of T. vaginalis. It was revealed by experiments in challenge animals that recombinant TvAP33 protein was capable of inducing partial protective effects in mice challenged with parasites. Moreover, as a vaccine candidate antigen, TvAP33 stimulated the production of Th2 cell immunity. In summary, the potential of TvAP33 as a novel antigen of $T$. vaginalis has been verified by the abovementioned experimental results, although the precise effect of cell adhesion exerted by $T$. vaginalis is still to be determined in the future.

\section{DATA AVAILABILITY STATEMENT}

The raw data supporting the conclusions of this article will be made available by the authors, without undue reservation, to any qualified researcher.

\section{ETHICS STATEMENT}

The animal study was reviewed and approved by the guidelines of the Animal Ethics Committee of the Xinxiang Medical University in Henan, China (Reference No. 2015016), was followed throughout all of the experiments of this study.

\section{AUTHOR CONTRIBUTIONS}

ZZ and XL conceived and designed the experiments, analyzed the data, and wrote the manuscript. YL and PW performed preparation of soluble trophozoite antigens and construction of the prokaryotic expression vector. HL and YD performed expression and purification of proteins of TvAP33 and 
pET-32a. LH and XS prepared antisera against recombined TvAP33 and T. vaginalis. ZZ and YZ completed immunoblotting and immunofluorescence. YL and SW performed $\mathrm{BALB} / \mathrm{c}$ mice immunization and challenge. XS and YS performed determination of antibodies by ELISA. XL and SW prepared the figures and tables. All authors read and approved the final manuscript.

\section{REFERENCES}

Abraham, M. C., Desjardins, M., Filion, L. G., and Garber, G. E. (1996). Inducible immunity to Trichomonas vaginalis in a mouse model of vaginal infection. Infect. Immun. 64, 3571-3575. doi: 10.1128/iai.64.9.3571-3575.1996

Alderete, J. F., and Garza, G. E. (1988). Identification and properties of Trichomonas vaginalis proteins involved in cytadherence. Infect. Immun. 56, 28-33. doi: 10.1128/iai.56.1.28-33.1988

Ardalan, S., Lee, B. C., and Garber, G. E. (2009). Trichomonas vaginalis: the adhesins AP51 and AP65 bind heme and hemoglobin. Exp. Parasitol. 121, 300-306. doi: 10.1016/j.exppara.2008.11.012

Arroyo, R., Engbring, J., and Alderete, J. F. (1992). Molecular basis of host epithelial cell recognition by Trichomonas vaginalis. Mol. Microbiol. 6, 853-862. doi: 10.1111/j.1365-2958.1992.tb01536.x

Beebe, A. M., Cua, D. J., and Malefyt, R. D. W. (2015). The role of interleukin10 in autoimmune disease: systemic lupus erythematosus (SLE) and multiple sclerosis (MS). Cytokine Growth Fact. Rev. 13, 403-412. doi: 10.1016/s13596101(02)00025-4

Bitencourt, F. G., De Brum Vieira, P., Meirelles, L. C., Rigo, G. V., Da Silva, E. F., Gnoatto, S. C. B., et al. (2018). Anti-Trichomonas vaginalis activity of ursolic acid derivative: a promising alternative. Parasitol. Res. 117, 1573-1580. doi: 10.1007/s00436-018-5839-1

Bradford, M. M. (1976). A rapid and sensitive method for the quantitation of microgram quantities of protein utilizing the principle of protein-dye binding. Anal. Biochem. 72, 248-254. doi: 10.1016/0003-2697(76)90527-3

Engbring, J. A., and Alderete, J. F. (1998a). Characterization of Trichomonas vaginalis AP33 adhesin and cell surface interactive domains. Microbiology 144(Pt 11), 3011-3018. doi: 10.1099/00221287-144-11-3011

Engbring, J. A., and Alderete, J. F. (1998b). Three genes encode distinct AP33 proteins involved in Trichomonas vaginalis cytoadherence. Mol. Microbiol. 28, 305-313. doi: 10.1046/j.1365-2958.1998.00784.x

Fiori, P. L., Diaz, N., Cocco, A. R., Rappelli, P., and Dessi, D. (2013). Association of Trichomonas vaginalis with its symbiont Mycoplasma hominis synergistically upregulates the in vitro proinflammatory response of human monocytes. Sex Transm. Infect. 89, 449-454.

Garcia, A. F., and Alderete, J. (2007). Characterization of the Trichomonas vaginalis surface-associated AP65 and binding domain interacting with trichomonads and host cells. BMC Microbiol. 7:116. doi: 10.1186/1471-2180-7-116

Graves, K. J., Ghosh, A. P., Schmidt, N., Augostini, P., Secor, W. E., Schwebke, J. R., et al. (2019). Trichomonas vaginalis virus among women with trichomoniasis and associations with demographics, clinical outcomes, and metronidazole resistance. Clin. Infect. Dis. 69, 2170-2176. doi: 10.1093/cid/ciz146

Hammond, T. L., Hankins, G. D., and Snyder, R. R. (1990). Transvaginal-peritoneal migration of Trichomonas vaginalis as a cause of ascites. A report of two cases. J. Reprod. Med. 35, 179-181.

Hernández, H., Sariego, I., and Garber, G. (2010). Monoclonal antibodies against a $62 \mathrm{kDa}$ proteinase of Trichomonas vaginalis decrease parasite cytoadherence to epithelial cells and confer protection in mice. Paras. Immunol. 26, 119-125. doi: 10.1111/j.0141-9838.2004.00690.x

Huang, H. C., Yu, S. F., Cai, M., Tan, F., and Pan, C. W. (2007). Preparation of monoclonal antibodies against the adhesion protein 33 of Trichomonas vaginalis. Chin. J. Parasitol. Parasit. Dis. 25, 97-100.

Isabelle, D., Kathy, J., Hanan, C., Sandrine, D., Nicolas, P., Laure, T., et al. (2013). Neonatal follicular Th cell responses are impaired and modulated by IL-4. J. Immunol. 191, 1231-1239. doi: 10.4049/jimmunol.1203288

Jarrett, O. D., Srinivasan, S., Richardson, B. A., Fiedler, T., Wallis, J. M., Kinuthia, J., et al. (2019). Specific vaginal bacteria are associated with an increased risk

\section{FUNDING}

This study obtained the funding from the National Natural Science Foundation of China (No. 81802028), the Doctoral Scientific Research Activation Foundation of the Xinxiang Medical University (Nos. XYBSKYZZ201631 and XYBSKYZZ201504).

of Trichomonas vaginalis Acquisition in women. J. Infect. Dis. 220, 1503-1510. doi: 10.1093/infdis/jiz354

Kassai, T., Cordero Del Campillo, M., Euzeby, J., Gaafar, S., Hiepe, T., and Himonas, C. A. (1988). Standardized nomenclature of animal parasitic diseases (SNOAPAD). Vet. Parasitol. 29, 299-326. doi: 10.1016/0304-4017(88)90148-3

Langston, M. E., Bhalla, A., Alderete, J. F., Nevin, R. L., Pakpahan, R., Hansen, J., et al. (2019). Trichomonas vaginalis infection and prostate-specific antigen concentration: insights into prostate involvement and prostate disease risk. Prostate 79, 1622-1628. doi: 10.1002/pros.23886

Li, H., Prasad, R., Katiyar, S. K., Yusuf, N., Elmets, C. A., and Xu, H. (2015). Interleukin-17 mediated inflammatory responses are required for ultraviolet radiation-induced immune suppression. Photochem. Photobiol. 91, 235-241. doi: $10.1111 /$ php. 12351

Liang, S. H., Huang, H. C., Pan, C. W., Xing, W. L., Qin, Q., Zhuge, Q. Y., et al. (2006). Preparation, characterization and preliminary application of recombinant protein AP33 of trichomonas vaginalis. Science 24:31.

Liao, W., Lin, J. X., and Leonard, W. J. (2011). IL-2 family cytokines: new insights into the complex roles of IL-2 as a broad regulator of T helper cell differentiation. Curr. Opin. Immunol. 23, 598-604. doi: 10.1016/j.coi.2011. 08.003

Ma, W. T., Yao, X. T., Peng, Q., and Chen, D. K. (2019). The protective and pathogenic roles of IL-17 in viral infections: friend or foe? Open Biol. 9:190109. doi: 10.1098/rsob.190109

Makarova, N., Henning, T., Taylor, A., Dinh, C., Lipscomb, J., Aubert, R., et al. (2017). Topical tenofovir protects against vaginal simian HIV infection in macaques coinfected with Chlamydia trachomatis and Trichomonas vaginalis. AIDS 31, 745-752. doi: 10.1097/qad.0000000000001389

Mavi, S. A., Modarressi, M. H., Mohebali, M., Shojaee, S., Zeraati, H., Teimouri, A., et al. (2019). Assessment of the immunogenicity and protective efficiency of a novel dual-promoter DNA vaccine, harboring SAG1 and GRA7 genes, from RH strain of Toxoplasma gondii in BALB/c mice. Infect. Drug Resist. 12, 2519-2530. doi: $10.2147 /$ idr.s209270

Mendoza-Oliveros, T., Arana-Argaez, V., Alvarez-Sanchez, L. C., Lara-Riegos, J., Alvarez-Sanchez, M. E., and Torres-Romero, J. C. (2019). Immune response of BALB/c mice toward putative calcium transporter recombinant protein of Trichomonas vaginalis. Korean J. Parasitol. 57, 33-38. doi: 10.3347/kjp.2019. 57.1 .33

Mirasol-Melendez, E., Brieba, L. G., Diaz-Quezada, C., Lopez-Hidalgo, M., Figueroa-Angulo, E. E., Avila-Gonzalez, L., et al. (2018). Characterization of multiple enolase genes from Trichomonas vaginalis. Potential novel targets for drug and vaccine design. Parasitol. Int. 67, 444-453. doi: 10.1016/j.parint.2018. 04.003

Mundodi, V., Kucknoor, A. S., and Alderete, J. F. (2007). Antisense RNA decreases AP33 gene expression and cytoadherence by T. vaginalis. BMC Microbiol. 7:64. doi: 10.1186/1471-2180-7-64

Nievas, Y. R., Vashisht, A. A., Corvi, M. M., Metz, S., Johnson, P. J., Wohlschlegel, J. A., et al. (2018). Protein palmitoylation plays an important role in Trichomonas vaginalis adherence. Mol. Cell Proteom. 17, 2229-2241. doi: 10. 1074/mcp.ra117.000018

Paintlia, M. K., Kaur, S., Gupta, I., Ganguly, N. K., Mahajan, R. C., and Malla, N. (2002). Specific IgA response, T-cell subtype and cytokine profile in experimental intravaginal trichomoniasis. Parasitol. Res. 88, 338-343. doi: 10. 1007/s004360100396

Patel, E. U., Gaydos, C. A., Packman, Z. R., Quinn, T. C., and Tobian, A. A. R. (2018). Prevalence and correlates of Trichomonas vaginalis infection among Men and women in the United States. Clin. Infect. Dis. 67, 211-217. doi: $10.1093 /$ cid/ciy079 
Peggy, R., Stephanie, T., Kai, S., and Guzmán, C. A. (2015). Rodents as pre-clinical models for predicting vaccine performance in humans. Expert Rev. Vaccines 14, 1213-1225. doi: 10.1586/14760584.2015.1074043

Phukan, N., Brooks, A. E. S., and Simoes-Barbosa, A. (2018). A cell surface aggregation-promoting factor from Lactobacillus gasseri contributes to inhibition of Trichomonas vaginalis adhesion to human vaginal ectocervical cells. Infect. Immun. 86:e0907-17.

Smith, J. D., and Garber, G. E. (2015). Trichomonas vaginalis infection induces vaginal CD4+ T-cell infiltration in a mouse model: a vaccine strategy to reduce vaginal infection and HIV transmission. J. Infect. Dis. 212, 285-293. doi: 10. 1093/infdis/jiv036

Su, Y., Wang, Q., Yang, B., Wu, L., Cheng, G., and Kuang, H. (2017). Withasteroid $B$ from D. metel L. regulates immune responses by modulating the JAK/STAT pathway and the IL-17+ RORÎtt $/$ IL-10+ FoxP3+ ratio. Clin. Exper. Immunol. 190, 40-53. doi: 10.1111/cei.12998

van Dalen, R., De La Cruz Diaz, J. S., Rumpret, M., Fuchsberger, F. F., Van Teijlingen, N. H., Hanske, J., et al. (2019). Langerhans cells sense Staphylococcus aureus wall teichoic acid through langerin to induce inflammatory responses. mBio 10:e0330-19.

Vargas Rigo, G., Petro-Silveira, B., Devereux, M., Mccann, M., Souza Dos Santos, A. L., and Tasca, T. (2019). Anti-Trichomonas vaginalis activity of 1,10-phenanthroline-5,6-dione-based metallodrugs and synergistic effect with metronidazole. Parasitology 146, 1179-1183. doi: 10.1017/s003118201800152x

Wei, H., Yin, L., Feng, S., Wang, X., Yang, K., Zhang, A., et al. (2015). Dualparallel inhibition of IL-10 and TGF- $\beta 1$ controls LPS-induced inflammatory response via NF-кB signaling in grass carp monocytes/macrophages. Fish Shellf. Immunol. 44, 445-452. doi: 10.1016/j.fsi.2015.03.023

World Health Organization (2012). Global Incidence And Prevalence Of Selected Curable Sexually Transmitted Infections: 2008. Geneva: World Health Organization.

Wright, J. F., Guo, Y., Quazi, A., Luxenberg, D. P., Bennett, F., Ross, J. F., et al. (2007). Identification of an IL-17F/IL-17A heterodimer in activated human CD4+ T cells. J. Biol. Chem. 282, 13447-13455.

Xie, Y. T., Gao, J. M., Wu, Y. P., Tang, P., Hide, G., Lai, D. H., et al. (2017). Recombinant alpha-actinin subunit antigens of Trichomonas vaginalis as potential vaccine candidates in protecting against trichomoniasis. Paras. Vect. $10: 83$.

Xu, X., Huang, H., Wang, Q., Cai, M., Qian, Y., Han, Y., et al. (2016). IFN$\gamma$-producing Th1-like regulatory $\mathrm{T}$ cells may limit acute cellular renal allograft rejection: Paradoxical post-transplantation effects of IFN- $\gamma$. Immunobiology 222:280. doi: 10.1016/j.imbio.2016.09.012

Yanming, S., Ruofeng, Y., Muleke, C. I., Guangwei, Z., Lixin, X., and Xiangrui, L. (2007). Vaccination of goats with recombinant galectin antigen induces partial protection against Haemonchus contortus infection. Paras. Immunol. 29, 319-326. doi: 10.1111/j.1365-3024.2007.00949.x

Yuan, L. J., and Gao, X. Z. (2005). Study on surface adhesion protein 33 gene sequence of different Trichomonas vaginalis isolates. Chin. J. Parasitol. Paras. Dis. 22, 353-356.

Zhang, Z., Kang, L., Wang, W., Zhao, X., Li, Y., Xie, Q., et al. (2018a). Prevalence and genetic diversity of Trichomonas vaginalis clinical isolates in a targeted population in Xinxiang City, Henan Province, China. Parasit Vect. 11:124.

Zhang, Z., Li, Y., Shuai, W., Xie, Q., Nan, X., Li, P., et al. (2018b). Molecular characterization and protective immunity of rhoptry protein 35 (ROP35) of Toxoplasma gondii as a DNA Vaccine. Vet. Parasitol. 260, 12-21. doi: 10.1016/ j.vetpar.2018.06.016

Zhang, Z., Li, Y., Wang, M., Xie, Q., Li, P., Zuo, S., et al. (2018c). Immune protection of rhoptry protein 21 (ROP21) of Toxoplasma gondii as a DNA vaccine against toxoplasmosis. Front. Microbiol. 9:909. doi: 10.3389/fmicb.2018. 00909

Zhang, Z., Li, Y., Li, H., Song, X., Ma, Z., Lu, H., et al. (2020). Identification of Toxoplasma gondii tyrosine hydroxylase (TH) activity and molecular immunoprotection against toxoplasmosis. Vaccines 8:E158.

Zhang, Z., Li, Y., Xie, Q., Li, P., Nan, X., Kong, L., et al. (2019). The molecular characterization and immunity identification of rhoptry protein 22 of Toxoplasma gondii as a DNA vaccine candidate against toxoplasmosis. J. Eukaryot. Microbiol. 66, 147-157. doi: 10.1111/jeu.12639

Conflict of Interest: The authors declare that the research was conducted in the absence of any commercial or financial relationships that could be construed as a potential conflict of interest.

Copyright (c) 2020 Zhang, Li, Wang, Hao, Zhu, Li, Song, Duan, Sang, Wu and Li. This is an open-access article distributed under the terms of the Creative Commons Attribution License (CC BY). The use, distribution or reproduction in other forums is permitted, provided the original author(s) and the copyright owner(s) are credited and that the original publication in this journal is cited, in accordance with accepted academic practice. No use, distribution or reproduction is permitted which does not comply with these terms. 